arts. He is survived by his wife, Barbara Savage, and two daughters.

Colleagues in the Political Science Department University of Arkansas, Fayetteville

\section{ROBERT H. SWANSBROUGH}

Robert Swansbrough was born on May 3, 1938, in Chicago, Illinois, and died in Chattanooga, Tennessee, on February 1, 2011.

Professor Swansbrough graduated with a BA in history from California State University at Long Beach (1961). He received his MA (1967) and his Ph.D. in political science (1972) from the University of California at Santa Barbara.

He served as a visiting assistant professor in the department of government at the College of William and Mary between September 1970 and June 1971 before joining the department of political science at the University of Tennessee at Chattanooga in August 1971. He was awarded tenure at UTC in 1974 and promoted to the rank of full professor in 1982. He also served as head of the department of political science between January 1981 and August 1992. His last administrative assignment was to serve as associate dean for the College of Arts and Sciences.
Professor Swansbrough was a distinguished teacher at both the undergraduate and the graduate levels. In addition, he was a committed and energetic scholar. His first book, The Embattled Colossus: Economic Nationalism and U.S. Investors in Latin America (University of Florida Press, 1976) was based on his doctoral dissertation. For a number of years afterward, he switched gears and produced a number of important monographs and book chapters dealing with Southern politics and political change in Tennessee. More recently, he became interested in studies of leadership. This resulted in a major book, Test by Fire: The War Presidency of George W. Bush (Palgrave, 2008). A number of his articles have appeared in various journals, including Political Psychology, Southeastern Political Review, Campaigns and Elections, Journal of Politics, and Issues in Higher Education.

Bob was selected as a 2009-2010 Fulbright Scholar to China, where he taught an undergraduate course in American government and a graduate seminar on U.S. foreign policy at Sichuan University. He was invited to give guest lectures at a number of leading Chinese universities on American politics and U.S. foreign policy. He kept a lively and informative blog during his stay in China.
In 1974, Professor Swansbrough served as Tennessee Third District campaign coordinator for Congresswoman Marilyn Lloyd (D) and then as her administrative assistant in Washington, DC, from 1975-77. He was no stranger to the Washington scene. As a Congressional Fellow of the APSA (1969-70), he served as a legislative assistant in the Washington offices of Oklahoma Senator Fred Harris and California Congressman John Tunney.

Bob served as a Division Officer, U.S. Navy, from 1961 to 1965 . At UTC, he was instrumental in reestablishing the ROTC program in 2007. In recognition of his service, he was presented with the General William E. Depuy Award by the U.S. Army Cadet Command at Fort Monroe in Hampton, Virginia.

Bob was often asked to offer his views as a political analyst for television stations and print publications.

His funeral was attended by an impressive cross-section of people, including former students, colleagues, and community activists from both political parties, in addition to family and close friends.

Fouad Moughrabi
University of Tennessee at Chattanooga




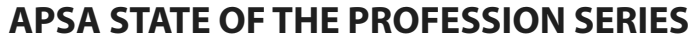 Publishing Political Science}

This guide to publishing in political science provides practical advice from leading political scientists and publishers. The book opens with a discussion of the state of publishing and review of publishing opportunities for political science.

\section{apsa}

The second part covers writing for particular venues and audiences such as literature reviews, textbooks, journals, blogs, and reference books. The third section provides practical advice from publishers on how to get your work published, including writing successful book proposals, establishing sound contract with a publisher, and understanding the journal peer review process.

A useful guide for ALL political scientists

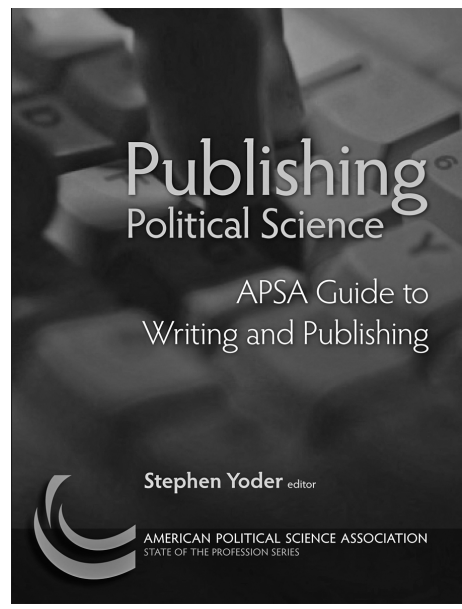

\section{CONTRIBUTORS}

EDITOR: Stephen Yoder, University of Maryland and former Managing Editor, PS: Political Science \& Politics

\section{State of Publishing}

Sharing What You Know

Beth Luey, Editorial consultant, Fairhaven, MA

Institutional Publishing and Political Science

Christopher J. Kelaher, Brookings Institution Press

Scholarly Book Publishing in Political Science:

A Hazardous Business

Sanford G. Thatcher, Penn State University Press

\section{How to Write-Specifics for Different Audiences}

The Write Stuff: Writing as a Performing and

Political Art

Thomas E. Cronin, Colorado College

Writing Introductions J

Jennifer L. Hochschild, Harvard University

How to Write a Literature Review

Jeffrey W. Knopf, Naval Postgraduate School and

Center for Contemporary Conflict, and

lain McMenamin, Dublin City College

Textbook Writing 101

Karen O'Connor, American University

There's More to Book Publishing in Political Science than Monographs: The Joy of Writing Reference Books Andrea Pedolsky, Doug Goldenberg-Hart, and Marc Segers, CQ Press
Editing Multi-Authored Books in Political Science:

Reflections on Twenty Year's of Experience

Clive S. Thomas, University of Alaska, Juneau, and

Ronald J. Hrebenar, University of Utah

Multidisciplinary Publishing: Reaching Those in

Other Disciplines

Mark C. Miller, Clark University

So You Want To Blog. . .

Daniel W. Drezner, Tufts University

\section{Topics in Publishing}

Seeing Your Name in Print: Unpacking the Mysteries of the Review Process at Political Science Scholarly Journals Andrew J. Polsky, Hunter College and the Graduate Center, CUNY

The Query Letter and Proposal as Sales Tools

Alex Holzman, Temple University Press

Negotiating a Book Contract with Grace, Finesse, and Success

Jennifer Knerr, Paradigm Publishers

The Etiquette of Publishing

Leanne Anderson, Lynne Rienner Publishers

\section{Order online at www.apsanet.org/pubs}

